\title{
Cases on Intercultural Communication: New Approach to Design
}

\author{
Elena G. Tareva ${ }^{\mathrm{a}}$ and Boris V. Tarev ${ }^{\mathrm{b} *}$ \\ ${ }^{a}$ Moscow City University \\ 4-1, 2nd Selskokhoziastvenny Proezd, Moscow, \\ 129226, Russia \\ ${ }^{b}$ National Research University Higher School of Economics \\ 20 Myasnitskaya Str., Moscow, 101000, Russia
}

Received 21.09.2018, received in revised form 26.09.2018, accepted 10.10.2018

The subject of the article is problem situations of intercultural communication, which lie in the basis of Case-studies - specialized descriptions of real situations containing problems, which must be analyzed and solved. The authors study approaches to the design of Case-studies that are necessary for the preparation of university students for participation in intercultural communication. The novelty of these Cases is to provide information that helps to deeply analyze the reality of other cultures and, through it, to rethink the participant's native picture of the world. Consequently, the aim of the article is to prove the role of the Case-study method in the development of intercultural communicative competence of students, which allows them to overcome the conflict of the dialogue of cultures. To achieve this goal, the following research methods were used: content analysis of verbal products of activity, questioning, survey, theoretical analysis and generalization of information received. As a result the article contains an example of a Case-study on intercultural communication issues, as well as the list of the most conflict-sensitive areas of intercultural interaction. The article may be of interest to specialists in the field of intercultural communication, Case-study designers, teachers of foreign languages, authors of textbooks on foreign languages.

Keywords: intercultural dialogue, intercultural conflict, problem aspects of intercultural communication, Case, Case method, Case design.

Research area: culturology.

Citation: Tareva, E.G., Tarev, B.V. (2018). Cases on intercultural communication: new approach todesign.J. Sib. Fed.Univ.Humanit. soc. sci., 11(10), 1699-1710.DOI: 10.17516/19971370-0329.

(C) Siberian Federal University. All rights reserved

* Corresponding author E-mail address: elenatareva@mail.ru; boristarev@mail.ru

This work is licensed under a Creative Commons Attribution-NonCommercial 4.0 International License (CC BY-NC 4.0). 


\section{Introduction}

The topicality of the problem addressed in the article is caused by the deepening of globalization processes, their multi-vector implementation, which, in addition to the objectively positive results achieved so far, simultaneously provokes the complication of international contacts, the problematic and often conflicting nature of interaction between representatives of different cultures, different values and priorities. The problem of conflict behavior in the communication process has become particularly acute in Russia recently, where domestic specialists should resist against information attacks in the international arena, presenting the world with a worthy and strong image of Russia and forming favorable public opinion about the country.

The current system of Russian higher education is seeking to find a dignified and prompt answer to the current urgent challenges of our time. It has to develop perspective trends that predetermine new teaching methods in the context of the ideology of the new human-oriented (anthropocentric) paradigm. Following the new formulas of the social order, graduates of universities should be ready, in addition to the traditional training outcomes, to make decisions in the course of communication with foreign partners, colleagues in various professional fields, including those situations of communication that are of a conflict nature.

Intercultural communicative competence should be actualized not only in favorable conditions of interaction, it also implies readiness to get out of a difficult situation caused by misunderstanding, disagreement, rejection of attitudes, different intentions of the participants in the dialogue. This readiness must be "triggered" in extreme conditions of communicative conflict, scale and destructive power of which can increase in the case when representatives of different states interact, especially in cases when this interaction is of confrontational character.

The research tasks are to conduct a theoretical analysis of conflictual intercultural situations, their parameters and properties, to identify the main difficulties in overcoming these situations, to conduct investigation and diagnostics of spheres and situations of intercultural communication, characterized by conflict nature of the dialogue participants' interaction, to suggest a list of such spheres and situations that can be described in Case-study design.

\section{Conflict as a part of intercultural communication}

Specific peculiarities of intercultural communication are determined by its characteristic features. One major feature could be relations between communicants 
belonging to different cultures. This indicator is specified through a number of additional parameters reflecting the specifics of the diversity of relations that is established between communication partners in the process of intercultural interaction.

The ideal image of intercultural communication is "drawn" quite simply. First, for effective intercultural communication, it is desirable that the nature of the relationship be maximally favorable for both communication partners. Only in this case mutual understanding is achieved, and this is the most desirable result of intercultural interaction. Secondly, taking into account the socio-cultural nature of communication between representatives of different communities contributes to the best achievement of mutual understanding in the intercultural dialogue. Thirdly, the indicator of "ideal" intercultural communication is the awareness by the communicants of their own "otherness", "otherness" of their culture, as well as the ability to assess its identity from the point of view of the communication partner. Fourth, with productive intercultural communication, two speakers communicate and two cultures interact; communicating, contacting each other, exchanging cultural information and each participant brings his own cultural meanings and values into communication. Thanks to these processes, a common, integral cultural background is created, and mutual enrichment of cultures takes place (Woodward, 2002).

The success of intercultural communication is predetermined by two main factors:

1) the model of communicative behavior should be conditioned, on the one hand, by the system of values and priorities of the culture of the communicative partner, on the other hand, by national, cultural and personal priorities, respect for the balance of interests, equality of cultural values;

2) knowledge, understanding and adequate interpretation of all components of the intercultural communicative situation is necessary, since it determines the topic of conversation, the choice of language tools and the entire strategy of the speakers' behavior.

Despite the simplicity and obviousness of these rules of building intercultural communication, not all acts of intercultural communication can be characterized as productive, positive for both sides, mutually beneficial. The share of such situations in the dialogue of cultures in which the conflict type of interaction manifests itself is rather numerous, and the unconstructive, confrontational model of communicative behavior is becoming more and more frequent (Baraldi, 2006).

Conflict in the structure of intercultural dialogue is inherently inevitable, it is imminent in such interaction, because it is based on confrontation - division into 
"one's own" and "others." Intercultural communication becomes a kind of crossroads, on which our own and other cultural codes converge (Dialog kul'tur, 2017). Belonging to a particular culture or several cultures influences the understanding of what is considered "normal" and "abnormal", "relevant" and "inappropriate", "expected" and "unexpected". If the person's expectations, perceptions and feelings do not coincide with the expectations, perceptions and feelings of the other subject, conflict not only can but even should arise.

The consequence of conflict situations of communication is tension in the relations of the parties, connected with misunderstanding or aversion of the other party, promotion or protection of one's own interests, unwillingness to search for mutually beneficial options. Conflict forms of interaction in communication exist along with manipulative forms that exert impact on the addressee, and cooperative forms aimed at cooperation and unification. In its turn, a conflict can take a constructive or destructive form and lead to destructive or creative consequences.

Professional communication is not an exception: in the course of its flow, certain standards of behavior are realized that are acceptable for one sociocultural community and are unacceptable for another. Mismatch of ideas about the picture of the world provokes the conflictual nature of intercultural professional communication, which hinders the achievement of significant goals and objectives, the solution of professionally significant problems, and the achievement of agreements on significant issues of interaction between representatives of business circles of different countries.

On the one hand, communication is affected by the factor of culture of dialogue: discourse on the same - even a very rigidly defined topic (for example, a business letter, an expression of condolence, speech at a meeting, an apology for being late, etc., not to mention traditional genres such as fairy tales or ritual formulas) is very different in terms of discursive rules (applied macro and microstructures) depending on the culture of the group within which this discourse is formed. So, in Southeast Asia the text of a business letter is built inductively: first, the reasons, the circumstances, and only at the end it contains the actual requirements or business proposals. For representatives of European and North American tradition, this style seems not clear and non-business. From their point of view, such a letter should begin with the formulation of a basic requirement or proposal, with its subsequent justification and detailed information.

On the other hand, communicative failures in the course of intercultural dialogue are predetermined by the factor of non-dialogue of cultures (for more details, see (Dialog kul'tur, 2017), meaning the deliberate reluctance of the two sides to seek compromises, 
to reach consensus in the relationship; each of them tries at all costs to insist on his point of view (sometimes even without bothering to listen to the opposite opinion). This kind of a "non-dialogue" may be, for example, related to differences in the understanding of the politeness category displayed by the interlocutors - the understanding that is based on solidarity or on maintaining a distance. So, Russians can appear impolite to the Germans, because the principle of solidarity with the communicative partner pushes them (Russians) to express their opinion and give advice in those cases when the German communicative culture, respecting the principle of autonomy and distance, treats it as obtrusiveness.

Moreover, the sources of conflict in the intercultural environment may lie in differences at the level of background knowledge. Just one example - the presence of different cultural associations on the word-stimulus "bread". At the word "bread" Russians often have the word-reaction "salt", the French have "wine", the Germans and Americans have "butter", and the Uzbeks have "tea" (Gorelov, Sedov, 1998).

The search for points of contact between different cultures can turn cultural disruptions into communicative bridges (Getmanenko, 2006). With the right methodical organization, the construction of such communicative bridges can remove the communicative conflict between representatives of different communities (Berthoin, Friedman, 2008).

\section{Case-study as a means of neutralizing intercultural conflicts}

In the context of the modern information society, Case-study, being relatively new method of training (for the first time it became known in the American business schools in the beginning of the $20^{\text {th }}$ century) is gaining increasing recognition in the sphere of higher education. This is primarily due to the change in the educational paradigm, which is directed not so much at transferring (receiving) specific knowledge, but rather at forming students' professional competence, skills and thinking skills, and developing personal abilities (Mostert, 2007). Simultaneously, the educational paradigm is transformed due to significant increase and drastic change in the requirements for the quality of training of a specialist who must have the ability of optimal behavior in various, including problematic, conflict situations.

Today, Case-study method has firmly entered the system of higher education. It has been analyzed in numerous works, where it is regarded as a method of teaching, educational technology, research strategy, form of control of training, a means of teaching (Dumez, 2015). In general, Case-study method is a part of the system of practice-oriented technologies that, along with visible advantages and productive 
potential, are accompanied by a number of difficulties (limitations) associated with their implementation in modern educational environment. Overcoming these difficulties is an actual pedagogical problem, which is considered in various subject areas, including the sphere of foreign language education.

At the basis of the Case-study method (the method for solving situational problems) is the precedent or case principle, taken from real life. At its core, Case can be defined as a description of the situation, which contains a problem, and a task of finding a solution to this problem. However, the problem itself is not explicated, its identification requires effort on the part of the students. The proposed situation, as a rule, is described from the point of view of a person who will make a decision based on the findings. Accordingly, an incorrectly defined problem leads to an incorrect algorithm of actions and to making incorrect decisions.

Practical-praxeological conditionality of a Case is well known: it is considered as an opportunity to record everyday practice, and also reproduce problem situations for learning purposes (Halverson, 2004). The didactic orientation of a Case consists in the fact that, when considering it, there is no single possible way of analyzing the situation, the correct answer, and this makes the learning situation problematic in its nature, involving learners in the creative search for ways to solve the task set in the Case.

The popularity of this method is based on the proximity to a real, professionally oriented model of behavior of future specialists in the conditions of professional interaction. This creates a sufficiently high degree of interest among students, and also contributes to raising their motivational level.

The essential characteristic of the Case-study method is the orientation to interpersonal communication, the impact on the mental and social structure of an individual. The organization of training aimed at finding a collective solution and its subsequent protection during discussion contributes to the development of speech and thinking skills and their implementation in the communication of participants during business game (Nkhoma, Sriratanaviriyakul, Le Quang, 2017).

Case-study method is a powerful tool of interactive, personally oriented strategy in teaching students, aimed at developing critical thinking, conceptual thinking, analytical skills and self-awareness, communication skills and leadership, ability to make decisions under conditions of uncertainty (Nkhoma, Sriratanaviriyakul, Le Quang, 2017). At the same time, the readiness for self-organization and selfgovernment is improving, organizational and managerial abilities, skills of public speaking, reasoning, expressiveness, addressing, etc., are being improved. 
The potential of Cases as an educational technology is very significant in the sphere of teaching students to make decisions in a complex non-standard situation of intercultural communication. Due to the fact that there is always a problem in the structure of the Case that is difficult to resolve, the content of this problem can be related to situations of intercultural interaction in which both sides are in the state of misunderstanding (aversion) of each other.

Case study on intercultural communication, the situation "Attitude to politics" (Author - E.G. Tareva).

It was the first Nastya's coming to France. The purpose of her stay in Metz is a two-month internship at the Faculty of Humanities, Arts and Culture of the University of Lorraine (Université de Lorraine). Before the trip, Nastia had a choice - to live in a hostel or in a family. After reflection, she decided to stay in a family, explaining that she would have a much higher level of French if she had to constantly communicate on various topics with native speakers.

The arrival in Metz was quite good. Nastya was met at the railway station by the head of the host family, Mr. N. There were no problems in communication during the first few days. On weekends, Nastya and family members walked a lot around the city, went on an excursion to Nancy. During conversations the topics raised were on culture, art, nature of Russia and France, the sights of the capitals of the two states. Nastya talked about the University, where she studied in Moscow, she shared her plans for the future.

Difficulties in communication began later. Nastya wanted to ask Mr. N about his attitude to the politics and economy of his country. To start the conversation, she decided to share her thoughts on the difficulties of Russian economic development. Wishing to draw attention to the issue under discussion, she criticized the EU's sanctions policy in general and France in particular in relation to the Russian Federation. Mr. $N$ did not support the topic of the conversation. He flatly refused to continue it, categorically declaring that this topic did not interest him and he was not going to discuss it with a foreigner. Nastya lost her temper and did not return to the topic.

From that moment on, there was no need to dream about getting close with family members. Nastya spent all her days at the University, trying to spend as little time as possible in the house. She regretted that she had not stayed at the hostel. It seemed to her that in a youth environment, communicating with peers from other countries who came, like her, to an internship in Metz, it would have been easier for her to discuss topics related to international events. 
Apparently, this Case is full of mutual misunderstanding, rejection of representatives of different cultures in life circumstances. Providing students with the opportunity to identify the source of misunderstanding, to determine the nature of the hostility based on different cultural values, will enable them to realize the importance of the cultural distancing factor, to reflect on how to minimize intercultural conflicts, how the students themselves would act in the place of the personalities described in the Case.

\section{Methodology and methods}

To identify the cases of intercultural communication that could provoke conflict in relations and actions of participants in the dialogue of cultures, in October-November 2017 a diagnostic study was conducted among students and teachers of the Institute of Foreign Languages of the Moscow City Pedagogical University (a total of 143 people participated). The following research methods were involved: a specialized questionnaire, activity analysis, and statistical processing of the data obtained.

When preparing the questionnaire (a total of 28 questions) on the SurveyMonkey platform (Available at: https: https://ru.surveymonkey.com/) - the world's leading company specializing in various kinds of surveys and results processing, the best practices for carrying out diagnostic studies in the field of intercultural communication were taken into account (Issers, Halvorson 2015; Martin, Nakayama 2005; Tareva, Schepilova, Tarev, 2017).

\section{Discussion}

The results obtained in the course of the survey of students made it possible to identify a spectrum of problems of intercultural communication, the solution of which is extremely difficult without specialized work with the application of the Case-study method. Below is the list of spheres and situations (circumstances) of communication that need formalization in the form of a Case-study for training students for intercultural communication.

\section{Problem situations of intercultural communication}

\section{Education:}

- educational process management (timetable, educational program, emphasis on independence and responsibility, etc.);

- academic discipline, adherence to the educational regime;

- relationship with participants of the educational process: students, teachers, managers; 
- educational values (priorities in education, self-development).

2. Everyday communication: in transport. in the host family. at a party. in cultural and leisure centers. in shops, in cafes, restaurants, in the service sector, in the financial sphere (banking operations, pocket (cash) money).

3. Recreation and leisure:

- tourism, travel (infrastructure, customs, value preferences, standards of conduct);

- free time (traditions in the organization of free time);

- cultural preferences (spiritual and (or) material dominants, attitude to art, cultural values);

- sports (preferences in sports, amateur and professional sports, attitude towards fans).

4. Confessional and spiritual values:

- attitude towards church;

- attitude towards polyconfessionality (mono-confessionality);

5. Social etiquette:

- attitude to sex-differentiation;

- attitude to age characteristics;

- attitude towards people with health specific.

6. Professional sphere:

- career ladder;

- working conditions (labor discipline, corporate standards, ethics of relationships in the working team, business etiquette);

- subordination (relations "boss-subordinate", "employee-employee”, "employeeclient");

- salary, various forms of incentives.

7. National cultural values and state priorities in the field of: politics. economic development. social security, arts and culture.

Case-studies designed on the basis of the mentioned above problem situations of intercultural communication should be characterized by the following parameters:

- to be as close as possible to the authentic situations that actually take place in the practice of intercultural dialogue;

- to be intercultural: to contain interculturally conditioned grounds for communication. In the process of Case analysis must be taken into account not only the specifics of different ways of thinking, but also there should take place the process of rethinking (comprehension) of individuals own values; 
- to be practical-oriented, aimed at overcoming really existing conflict situations of intercultural interaction;

- contain controversial issues or conflict issues that lead to the search for alternative solutions and discussions, the end result of which is the adoption of an optimal solution through discussion.

If correspondent to these parameters, the Case can serve as a model of the studied culture, become a part of other reality and reflect the specifics of the other society in comparison with the native linguoculture.

\section{Conclusion}

Achievement of positive results in the course of intercultural communication is an extremely complex process that requires the availability of special knowledge, skills, abilities, and personal qualities of participants in the dialogue of cultures. The development of these competencies and abilities is one of the important tasks of modern Russian education, which is striving to prepare graduates of a new generation, ready to live in a world full of conflicts, primarily of intercultural nature. The desire to search for new approaches, methods, techniques, development (processing) of the available means and methods that provide this kind of training is a sign of modern educational space, and the Case-study method plays an important role in this process. At a time when textbooks are clearly late in providing content and technologies aimed at applying the intercultural approach in the practice of teaching foreign languages, a series of practice-oriented technologies, first of all a Case-study method that reflects the actual conflictual reality of intercultural relations, has come. Correctly designed Case-study, focused on comprehension, analysis of the essence of the intercultural problem and on the adoption of a personally conditioned version of its solution, will allow to remove or at least reduce discomfort in intercultural relations and ensure the effectiveness of contacts at various levels of interstate relations.

\section{References}

Dialog kul'tur. Kul'tura dialoga: chelovek i novye sociogumanitarnye cennosti: [Dialogue of cultures. Culture of dialogue: Human Being and New Socio-cultural Values] (2017). Monograph. Moscow, 424 p.

Dumez, H. (2015). What is a Case, and what is a Case study? In Bulletin of Sociological Methodology, 127 (1), 43-57. DOI: https://doi.org/10.1177/0759106315582200 
Halverson, R. (2004). Accessing, documenting and communicating the phronesis of school leadership practice. In American Journal of Education, 111 (1), 90-122.

Issers, O., Halvorson, S.A. (2015). Cross-cultural study of american and russian proprieties in communication. In Vestnik Rossijskogo universiteta druzhby narodov. Serija: Lingvistika [Bulletin of the Russian University of People' Friendship. Series: Linguistics], 19 (4), 146-154.

Martin, J.N., Nakayama, T.K. (2005). Experiencing intercultural communication: Anintroduction. 2nd ed. Boston: McGraw Hill, 347 p.

Mostert, M.P. (2007). Challenges of Case-Based Teaching. In The Behavior Analyst Today, 8 (4), 434-442.

Tareva, E.G., Schepilova, A.V., Tarev, B.V. (2017) Intercultural Content of a Foreign Language Textbooks: Concept, Texts, Practices. In XLinguae Journal, 10 (3), 246-255. DOI: 10.18355/XL.2017.10.03.20

Woodward, K. (2002). Identity and Difference. London: SAGE publications Ltd., $363 \mathrm{p}$.

Baraldi, C. (2006). New forms of intercultural communication in a globalized world international communication. In Gazette, 68 (1), 53-69. DOI: https://doi. org/10.1177/1748048506060115

Berthoin, A.A., Friedman, V.J. (2008). Learning to negotiate reality: a strategy for teaching intercultural competencies. In Journal of Management Education, 32 (3), 363-386. DOI: https://doi.org/10.1177/1052562907308794

Nkhoma, M., Sriratanaviriyakul, N., Le Quang, H. (2017). Using case method to enrich students' learning outcomes. In Active Learning in Higher Education, 18 (1), 37-50. DOI: https://doi.org/10.1177/1469787417693501.

Gorelov, I.N., Sedov, K.F. (1998). Osnovy psiholingvistiki [Basics of Psycholinguistics]. Moscow, 256 p.

Getmanenko, N. (2006). Kul'turnyj shok? jeto izlechimo! [Cultural Shock? It is curable!]. In Russkij jazyk za rubezhom [Russian language abroad], 2 (196). 80-88. 


\title{
Кейсы по межкультурной коммуникации: \\ новый подход к моделированию
}

\author{
Е.Г. Тарева ${ }^{a}$, Б.В. Тарев ${ }^{\sigma}$ \\ ${ }^{a}$ Московский городской педагогический университет \\ Россия, 129226, Москва, 2-й Сельскохозяйственный проезд, 4-1 \\ ${ }^{6}$ Национальный исследовательский университет \\ «Высшая школа экономики» \\ Россия, 101000, Москва, ул. Мясниијкая, 20
}

Предметом рассмотрения в данной статье являются проблемные ситуачии межкультурной коммуникации, лежащие в основе кейса - специиализированного описания реального контекста, содержащего проблему, необходимую для решения. Авторы изучают подходы кразработке кейсов, необходимых для подготовки студентов вузов кучастию в межкультурной коммуникации. Новизна этих кейсов заключается в предоставлении информации, служащей для глубокого анализа инокультурной реальности и через нее переосмысления родной картинь мира. Следовательно, иелью статьи является доказательство роли кейс-метода в формировании межкультурной коммуникативной компетениии обучающихся, позволяющей преодолеть конфликт диалога культур. Для достижения ичели использованы следующие методы исследования: контент-анализ вербальных продуктов деятельности, анкетирование, опрос, теоретический анализ и обобщение полученной информачии. В качестве результата в статье приводится пример учебного кейса по проблемам межкультурной коммуникации, а также представлен список наиболее конфликтогенных сфер межкультурного взаимодействия, которые должны быть обработаны в формате кейса. Статья может быть интересна специиалистам в области межкультурной коммуникации, разработчикам кейсов, преподавателям иностранных языков, авторам учебников по иностранным языкам.

Ключевые слова: межкультурный диалог, межкультурный конфликт, проблемные аспекты межккльтурной коммуникации, кейс, кейс-метод, модель кейса.

Научная специальность: 24.00.00 - культурология. 